\title{
The collaboration of investigative authorities in Uganda: Current issues in criminal matters
}

\author{
By Asiimwe Jackline*
}

\begin{abstract}
This piece of academic work analyses investigative collaboration as an a viable resolution in conducting investigation into cases of complex nature that a single government institution cannot investigate on its own; pooling resources into investigating a case of a great national interest; restoring public trust in investigative institutions so that individuals do not take the law into their hands in stances where the public feels that the state has failed to protect them from criminals, as well as uncovering, preserving, and collecting evidence on first hand criminal cases. Further, the paper defines the concept of investigation, cites examples of investigative institutions in Uganda and their roles, explains tools used in collaborative investigation and points out instances of collaborative. Also, the paper discusses the challenges of collaborative investigation and reference is made to current issues in criminal. Last but not least, the paper draws relevant conclusions and makes recommendations.
\end{abstract}

\section{A. INTRODUCTION}

The Uganda criminal justice system is an adversarial one based on the English law. The accused is presumed to be innocent until proven guilty. ${ }^{1}$ The burden is therefore on the prosecution to prove the guilt of the accused beyond a reasonable doubt. A criminal trial cannot be successful unless there is effective investigation. In Uganda, the main agencies working on issues connected with complex crimes include institutional authorities such as the Uganda Police, the Directorate of Public Prosecutions (DPP), the Inspector General of Government (IGG), and the Auditor General (AG), all of which have long histories and divergent tasks defined in the legislation. Each authority has its goals that differ from the goals of the other. For example, criminal investigations are mainly carried out by the police, whereas the Constitution of the Republic of Uganda empowers the DPP to direct the police to investigate any matter of criminal nature and report to the DPP expeditiously. ${ }^{2}$ Given the increa-

* The author is currently a Lecturer, Kyambogo University,Uganda, previously served as a Legal Research Officer, Attached to the chambers of the Deputy Chief Justice in the Court of Appeal of Uganda, Legal Consultant of AWEPA, South Sudan, Legal Consultant with TrustAfrica as well as Legal Consultant, Corporate and Regulatory Affairs, MTN South Sudan. (email:asiimwejackline4@yahoo.com).

1 Article 28 (3) (a) of the Constitution of Republic of Uganda, 1995 (as amended).

2 Article 120 of the Constitution of Republic of Uganda, 1995 (as amended). 
sing complexity of crimes and the need to share information between organizations, the investigation has moved a long way from the hierarchical organization of work toward interorganizational and network-type collaboration. ${ }^{3}$

\section{B. The Concept of Collaborative Investigation}

The term investigation is a pre-trial process which looks into or conducts an inquiry into a matter systematically in order to make the suspect subject of a criminal trial. ${ }^{4}$ When an offence is alleged to have been committed, the police has the mandate to carry out investigations with the aim of obtaining the necessary evidence that will be used in court to warrant a conviction so as to punish criminals, to protect life and property preserve law and order as well as preventing and detecting crime ${ }^{5}$. It should be noted that poor investigation leads to acquittal of guilty individuals on one hand and conviction of innocent parties on the other. Being a part and parcel of the criminal justice system, a good investigation into an offence helps the state in proving the guilt of the accused beyond reasonable doubt, and ensures that chances of convicting an innocent person are avoided. When an offence has been well investigated, the trial process becomes easier and expeditious and this can only be possible when there is effective cooperation among investigative institutions. A criminal investigative failure more commonly results in the offender escaping justice (a wrongful conviction also allows the real offender to go free). The damage resulting from criminal investigative failures, whether to victims, innocent people, or the public, is significant. Thus, collaborative investigation simply refers to investigative institutions working together in execution of their investigatory roles.

As such, when a crime is alleged to have been committed, the investigative agencies must ensure that:

\section{That a crime created by the law has been committed and}

II. That the person who committed the crime is the accused person and has been placed squarely at the scene of the crime.

Without placing the accused at the scene of the crime, the prosecution will fail in its mandate to secure a conviction. In order to place the accused at the scene of the crime, investigations must be carried out to collect relevant evidence that supports the charge and

3 Anne Puonti, "Learning To Work Together: Collaboration between Authorities in Economic Crime Investigation", University of Helsinki Faculty of Behavioural Sciences Center for Activity Theory and Developmental Work Research, (Vantaa Finland, 2004.), p. 9. ISBN 952-10-1702-3.

4 Bryan, A., Garner, (editor), Black's Law Dictionary, USA, West Publishing, (8 ${ }^{\text {th }}$ Edition, 1990), p. 844. ISBN 90-6544-631-1.

5 Article 212 of the Constitution of Republic of Uganda, 1995 (as amended). 
confirms that the accused was involved in committing the crime in question at the time and place mentioned in the charge.

Noteworthy, different crimes call for different methods of investigation. There are general principles that an investigator can follow to investigate a crime namely: interviewing witnesses $^{6}$, conducting an identification parade ${ }^{7}$, visiting the scene of crime ${ }^{8}$, use of experts ${ }^{9}$, conducting searches, use of exhibits, and use of sketch plans ${ }^{10}$ among others.

It is important to point out at this stage that because different types of crimes require different methods of investigation, these methods do require various kinds of expertise, both human and financial resources, which are not vested in one government institution and thus the need for the involvement of two or even more institutions thereby giving rise to collaboration among investigative authorities in Uganda.

\section{RATIONALE OF COLLABORATIVE INVESTIGATION}

The Purpose of a collaborative investigation is to:

\section{To conduct investigation into cases of complex nature that a single government institution cannot investigate on its own;}

\section{To pool resources into investigating a case of a great national interest;}

III. To restore public trust in investigative institutions so that individuals do not take the law into their hands in stances where the public feels that the state has failed to protect them from criminals, and

\section{To uncover, preserve, and collect evidence on first hand criminal cases.}

In collaborative investigation, one institution uses its ability to look into what it knows how to do best and allows another institution or personnel do what it cannot do. Collaboration between authorities is easily understood as the interaction, relations and mutual interdependency involved in the shared field of investigation. But without the notion of the object, the collaboration easily remains a loose and ambiguous concept. Such a notion enables us to grasp the multi-organizational field of divergent agencies by following those who takes part

6 In interviewing a witness, the investigator must interview a an eye witness who saw the accused committing the offence, or a person who knows about the commission of the offence, as well as the accused himself should be interviewed and the statement recorded.

7 Ssentale v. Uganda [1968] E.A, p.365.

8 A scene of crime is any place where a crime took place wholly or partially.

9 Some offences require expert opinion due to technicality involved. Experts such as pathologists, ballistic experts, government chemists, finger print experts, bomb experts, and DNA experts are increasingly being used.

10 The scene of crime officer should visually represent the scene of the crime through a sketch plan. This helps court to visualize what took place at the scene of crime without court visiting the scene. 
in the object construction. ${ }^{11}$ Collaboration between authorities is a necessity in complex crime investigation such as economic crimes, crimes related to terrorism, money laundering among others because the necessary information and knowledge are distributed among them.

Further more, institutional collaboration in criminal investigating seems to be a social order for innovations in crime investigation because studies on police efficiency have not been complimentary about the police and their capacity to tackle crime has been seriously questioned by researchers in recent decades. ${ }^{12}$ This is true in the case of Uganda where various inquiries into the Uganda Police have revealed that the Police force is the most corrupt $^{13}$ and thus there is need for a collaboration between the police and the other investigative authorities such as the IGG and the Auditor General of Government so as lessen challenges posed by corruption in the police. Growing challenges from crime in terms of complexity and increasing increasing diversity and multitude of crime in this modern society has been giving more and more challenges to criminal justice authorities, hence the need for collaborative investigation.

\section{TOOLS USED IN COLLABORATIVE INVESTIGATION}

Collaborative investigation tools are somewhat different from the usual such as the telephone, the computer and information-gathering tools. Collaboration is managed by using and developing various collaborative tools that manipulate and carry information between participants such as the planning tools and information management tools. ${ }^{14}$ These tools are of two types: vertical and horizontal tools as well as standardized and locally constructed tools. Vertical tools are typically designed for intra-organizational use, and they may, despite their good properties, be difficult to use across organizations. Horizontal tools are interorganizational and are used to complement vertical tools. ${ }^{15}$

The most interesting tools used in the investigation process included house search plans and graphic models of the crime under investigation. House search plans do not have a

11 Puonti, A., "Learning To Work Together: Collaboration between Authorities in Economic-Crime Investigation", University of Helsinki Faculty of Behavioural Sciences Center for Activity Theory and Developmental Work Research and National Bureau of Investigation, Vantaa Finland, 2004, at p.35.

12 Bowling, B., and Foster, J. Policing and the Police cited in M. Maguire, R. Morgan and R: Reiner (Eds) The Oxford Handbook of Criminology Oxford, (Oxford University Press, 2002). See also Eck, 1999, Skolnick and Bayley 1986.

13 Police Top Corrupt Institutions See: http://www.newvision.co.ug/new_vision/news/1413659/polic e-corrupt-institution-report (accessed on 29/8/2016) The survey, based on 2,400 Ugandan respondents, puts police at $63 \%$ on the corruption index, followed by tax officials and government officials at $48 \%$ each. Judges and magistrates follow closely at $45 \%$, the public sector at $44 \%$ and business executives at $40 \%$.

14 Supra note 11.

15 Ibid. 
standardized form; they are constructed case by case according to the main investigator's ideas. They are locally constructed, and used both vertically (to give orders within an organization) and horizontally (as the agenda for an interorganizational planning meeting). The emerging tools include an interesting, locally constructed document called a project plan, which consists of sections regarding the crime, goals, information exchange, and feedback. Another local innovation is the construction of a case database shared by all participants who have access to police files.

\section{E. INVESTIGATIVE INSTITUTIONS IN UGANDA}

In Uganda, there are several institutions clothed with the legal mandate to investigate with the scope of operation set out in the law establishing each institution. More than often, one institution may require the intervention of another in order to obtain sufficient evidence hence the need for investigative collaboration. Therefore, this sections briefly outlines some of the investigative institutions and their roles.

\section{The Uganda Police Force (UPF)}

The Uganda Police is established under the Constitution. ${ }^{16}$ The functions of the police are laid down in Article 212 of the Constitution of the Republic of Uganda. The Police Act also re-echoes the functions of the police namely:

1. to protect life and property;

2. to preserve law and order;

3. to prevent and detect crime; and

4. to cooperate with the civilian authority and other security organs established under the Constitution and with the population generally, the police as the law enforcers are there to make sure that everyone including the police force itself follows the law at every step.

On the other hand, the Criminal Procedure Code $\operatorname{Act}^{17}$ sets out the procedures to be followed by police and the Penal Code Act $^{18}$ outlines offenses and punishments prescribed by law.

The Criminal Investigations Department (CID) is responsible for detecting, preventing and investigating crime, compiling information on criminals and gathering evidence for use in criminal prosecutions. Other branches and units of the Uganda Police Force, include the Legal Department); the Child and Family Protection Unit, which deals with human rights and gender-related issues, the Police Anti-Terrorism Unit, responsible for such activities as diffusing bombs, rescuing hostages and apprehending "terrorists", the Mobile Police Patrol

16 Article 211.

17 Sections 2-11 of Criminal Procedure Code Act, Cap.116, Laws of Uganda, 2000.

18 Cap.120, Laws of Uganda, 2000 edition. 
Unit (MPPU), which deals with border crimes, including smuggling; and the Special Force Unit, a paramilitary branch of the police trained in riot control and border patrol. ${ }^{19}$

\section{The Directorate of Public Prosecution (DPP)}

The office of the DPP is also established by the Constitution. ${ }^{20}$ The DPP has the mandate over all criminal prosecutions in the country, including corruption cases. This is derived from the functions of the DPP which include:

1. to direct the police to investigate any information of a criminal nature and report to him or her expeditiously ${ }^{21}$;

2. to institute criminal proceedings against any person or authority in any court with competent jurisdiction other than court martial ${ }^{22}$;

3. to take over and continue any criminal proceedings instituted by any other person or authority ${ }^{23}$; and

4. to discontinue at any stage before judgment is delivered any criminal proceedings instituted by himself or herself or any other person or authority; except that the DPP shall not discontinue any proceedings by another person or authority except with the consent of court. ${ }^{24}$

It should be noted that in exercise of the functions conferred on him or her, the DPP is not be subject to the direction or control of any person or authority. ${ }^{25}$ However, in exercise of these powers, the DPP shall have regard to public interest, the interest of the administration of justice, and the need to prevent abuse of the legal process. ${ }^{26}$ The DPP does not carry out investigation of cases. This is the function of the police. The role of the DPP is to guide and advise the police in the conduct of the investigations. The cases are reported to the police who carry out investigations and refer the case to the DPP for legal advice and to conduct the prosecution. The prosecutions are done in the Magistrates courts, although the DPP has powers to commit any case to the High Court for trial.

\section{The Inspectorate of Government (IGG)}

The IGG is established by Article 223 of the Constitution. The IGG has powers to investigate, cause investigation, arrest, cause arrest, prosecute, or cause prosecution in respect of

19 Supra.

20 Article $120(1)$.

21 Article 120 (3) (a).

22 Article 120 (3) (b).

23 Article 120 (3) (c).

24 Article 120 (3) (d).

25 Article 120 (6) and (7).

26 Article 120 (5). 
cases involving corruption, abuse of authority or of public office. ${ }^{27}$ The major difference in the roles of the DPP and IGG is that while the IGG has powers to investigate, arrest and prosecute offenders, as already stated, the DPP does not investigate or arrest but relies on the police for investigations and arrest. ${ }^{28}$ Secondly, while the DPP has powers to control and handle all criminal prosecutions in the country, IGG handles investigations and prosecutions only in corruption cases, and cases of abuse of authority or public office. Corruption cases are defined both in the Anti-Corruption $\mathrm{Act}^{29}$ and in the IGG $\mathrm{Act}^{30}$ to include embezzlement, bribery, nepotism, influence peddling, theft of public funds or assets, fraud, forgery, causing financial or property loss and false accounting in public affairs. In investigation of corruption, Uganda's Prevention of Corruption Act gives the DPP powers to: cause the investigation of any bank account, share account or purchase account; apply to court for orders restricting disposal of assets or bank accounts of accused persons; order the inspection of documents and obtaining of copies thereof; and, to obtain information. The same powers apply to the offences of embezzlement and causing financial loss under the Penal Code. ${ }^{31}$

The above offences are investigated by mainly a specialized fraud squad of the Criminal Investigations Department (CID) based at the Police Headquarters or the investigators of the Inspector General of Government (IGG). Inputs are sought from experts in the affected organizations and others, especially auditors from the Office of the Auditor General, and document analysts or handwriting experts from the Government Analytical Laboratory. The auditors are useful in unearthing financial irregularities or malpractices while document examiners mainly deal with the identification and analysis of handwriting, signatures, alterations, erasures, embossments and stamp impressions. In some cases the input of the Public Procurement and Disposal of Assets Authority (PPDA) may be required to identify procurement irregularities and malpractices.

\section{The Government Chemist}

The Government Chemist Laboratory is a vital department as far investigation of criminal cases is concerned. In their day to day operations, the CID submit to the government chemist specimens relevant to their on-going investigations. The specimens may include blood, poison and poisonous substances, human tissue to mention a few. The government chemist examines them and prepares a report on the basis of which the CID determines whether and offence has been committed or not. There is only one office of the Government Chemist

27 Article 225(2); The Inspectorate of Government may investigate any matter referred to in clause (1) (a) of this article, on its own initiative or upon complaint made to it by any member of the public, whether or not that person has personally suffered any injustice by reason of that matter.

28 Anti-Corruption Act 6, of 2009.

29 Anti-Corruption Act 6, of 2009.

30 Inspectorate of Government Act, 2002.

31 Cap.120, Laws of Uganda, 2000. 
situated in Wandegeya, Kampala. Samples from all over the country are sent here for analysis by the police. In all cases, a police office is dispatched to deliver the samples and collect them when they are ready. The department is understaffed and ill-equipped to handle the multitude of requests it is expected to handle. The shortage negatively affects the efficiency of the CID in investigations.

\section{The Uganda Human Rights Commission (UHRC)}

The UHRC is also established by the Constitution. ${ }^{32}$ The functions of Commission inter alia include: to investigate at its own initiative or on a complaint made by any person or group of persons against the violation any human right. ${ }^{33}$ It should be noted that he nature of the work police does legally deprive members of society some human rights. ${ }^{34}$ In this way the UHRC checks the abuse of powers of the police. It is also mandated to establish continuing program of research, education and information to enhance respect of human rights. ${ }^{35}$

\section{Other Institutions}

Additionally, there are other institutions which carry out investigations and these include; the Auditor General, Uganda People's Defence Forces and its Chieftaincy of Military Intelligence (CMI), Special Investigation Unit(SIU), External Security Organization (ESO), Internal Security Organization (ISO), the Joint Anti-Terrorism Taskforce and Uganda Prisons. Last but not least, there if the recently established Financial Intelligence Authority (FIA). The objectives of FIA include inter alia to enhance the identification of the proceeds of crime and the combating of money laundering and illicit financial transfers from Uganda. ${ }^{36}$

\section{F. UGANDA AND COLLABORATIVE INVESTIGATION IN CRIMINAL CASES}

It should be noted that collaborative investigation is an ideal form of investigation for Uganda in particular. In Uganda, there are instances where collaborative investigation techniques have been employed and have yielded positive results. However, there are instances where these techniques have been neglected leading to obtaining weak evidence which leads to wrong acquittal or convictions hence, defeating the ends of justice.

In the case of the 13 July 2010 Kampala twin bombings, as Ugandans watched the FIFA World Cup 2010 finals in South Africa, between Spain and Holland, the thirteen sus-

32 Article 51.

33 Article 52 (1) (a).

34 Chapter IV of the Constitution: Such rights include protection of personal liberty, protection from deprivation of property, right to privacy, right to a speedy and fair hearing, protection of freedom of conscience, expression movement, religion assembly and association.

35 Article 52 (1) (c).

36 Section 19 (a) of the Anti-Money Laundering Act, 2013. 
pects (seven Kenyans, five Ugandans and One Tanzanian); these "bunch of thugs" connived, abetted, orchestrated and helped carry out the attacks at the Kyadondo Rugby grounds and in Ethiopian Village in Muyenga in Kampala-Uganda and drove the entire continent into furry. Fifteen people, majority foreigners died on spot due to the Muyenga attack. Then just around $11.18 \mathrm{pm}$ at Kyadondo, another attack occurred, leaving over 50 revellers dead and hundreds injured. Following the attacks, security agencies from Uganda, neighbouring countries, Interpol and US dreaded CIA and FBI swung into action leading to arrests of over 60 suspects. Others were arrested from neighbouring Kenya, Rwanda and Tanzania. ${ }^{37}$

Indeed, in complex criminal cases such as this, co-operation is key in ensuring convictions. The accused were convicted and sentenced to death, for the murder of 76 people and over 100 injured on July 10, 2010 as they watched the South African World Cup final at Kyadondo Rugby grounds in Lugogo along Jinja Road and at the Ethiopian Village in Muyenga. ${ }^{38}$ The facial reconstruction by FBI of the two suicide bombers heads found at Lugogo, indicated that one was of Somali origin, while another was black, believed to be a Ugandan or Kenyan. None of the bodies of the two suspects were claimed by relatives until they were disposed off. The evidence showed that the attacks were planned in Somalia, and the explosives transported to Uganda via Kenya. Incidentally, it was through concerted regional collaboration and co-operation that Ugandan authorities were able to get the evidence they needed in this case.

Nevertheless, currently, no much attention has been paid to the phenomenon of collaborative investigation in Uganda as investigation largely remains the preserve of the police and the Director of Public Prosecution who tend to guard their roles in investigation jealously. This leads us to challenges involved in collaborative Investigation; while taking a keen look at current criminal matters.

\section{G. CHALLENGES INVOLVED IN COLLABORATIVE INVESTIGATION: CURRENT ISSUES IN CRIMINAL MATTERS}

\section{Conflict of Interest among Investigative Institutions}

Instances may arise where the interest of a given investigative institution is at stake. A case in point is the recent prosecution of the Inspector General of Police. In this issue, the private prosecution of the Uganda Inspector General of Police Gen Kale Kayihura and 7 others under the Prevention and Prohibition of Torture Act which allows for individual culpability ${ }^{39}$ arises from beatings the police meted out on supporters of opposition politician

37 Jaramogi, P., Justice at Last: 8 of the 13 July 2010 Bomb Suspects are Convicted by Aphonse Owinyi Dollo, 5 Acquitted,due to Lack of Incriminating Evidence: Available on: http://theinvestigatorn ews.com/2016/05/justice-at-last-8-of-the-13-july-2010-bomb-suspects-are-convicted-by-alphonseowinyi-dollo-5-acquitted-due-to-lack-of-incriminating-evidence(Accessed on $26^{\text {th }}$ August 2016.

38 Ibid.

39 Torture Act, 2010. 
Dr.Kizza Besigye following his release on bail July 12, 2016. On July 14, 2016, police officers commanded by Kaggwa circled boda-boda riders near Busaabala Road junction off Entebbe Road and beat them as they accompanied Dr. Besigye who was heading to the FDC party headquarters.

On the day when the IGP was supposed to appear in court to answer the said charges, demonstrations in protest of the scheduled trial clouded Makindye Chief Magistrates' Court. The unruly supporters chanted and ran round the court premises with some closing the door to the chambers of the Chief Magistrate Richard Mafabi, a move some observers interpreted as effort to intimidate the magistrate from convening and hearing the case. The anarchy progressed as police officers deployed at the court premises looked on. As this chaos was raging, a crisis meeting was held in the chambers of the Chief Magistrate between the private prosecutors, representatives of the IGP. ${ }^{40}$

Before the hearing could take place, the DPP notified the Magistrates Court that he would take over the trial of the IGP as per his Constitutional mandate. ${ }^{41}$ The Magistrate denied the application of the DPP to take over of the case. The DPP applied to High Court in Kampala to review a decision of Makindye Magistrate's Court decision which had denied him to automatically take over the prosecution of Gen Kayihura. ${ }^{42}$ The lawyers for the prosecution, under the Network of Public Interest Lawyers (NETPIL) who instituted the proceedings, had expressed concern that the DPP might terminate the case if he took over. The Makerere law don Dr. Daniel Ruhweza says DPP is practicing his constitutional mandate to institute or take over case but has his reservations. "The worry was what would happen if DPP took over a case in which IGP is indicted. How would the police investigate the case?"43 The DPP works together with the police in investigation; in this case there is already conflict of interest hence a challenge to investigative collaboration.

On Friday the 26/08/2016, three days to the date scheduled for the re-appearance of the IGP in court, the Deputy Chief justice issued and interim injunction to block the trial. ${ }^{44}$ This application arose from the main petition, which challenges the legality of the torture charges. ${ }^{45}$ Justice Kavuma said he based his ruling on the consent of both parties and orde-

40 Supra.

41 Article 120(3)(c).

42 Court summons Kayihura for torturing Ugandans.

43 Makerere Law Don Attacks DPP over Kayihura Case (http://www.theinsider.ug/makerere-law-don -attacks-dpp-over-kayihura-case/ accessed on 08/18/2016).

44 Justice Kavuma halts case against the IGP Kale Kayihura, www.theinsider.ug/kavuma-issues-interim-order-halting-kayihura-trial/ (accessed on 31/08/2016.

45 http://ntv.co.ug/news/local/26/aug/2016/justice-kavuma-halts-case-against-igp-kale-kayihura-1399 1\#sthash.Xpk6AEsV.dpuf, Justice Kavuma said an interim application would stay in place until the main petition is heard and determined by the court. Deputy Chief Justice Steven Kavuma has issued an interim order halting the prosecution of IGP Kale Kayihura over torture charges before Makindye Magistrates court. The interim application was filed by a Kampala advocate, Robert Lutalo, which sought to block the criminal trial of IGP Kale Kayihura and 7 other senior police commanders. Robert Lutalo had petitioned the constitutional court early this month challenging the 
red that the said interim application stays in place until the main petition is heard and determined by the court but he will give the full reasons for his decision on notice. Analysts have stated that this is a move calculated to protect the ruling party stalwart-General Kayihura. It is rather an absurd and blatant violation of rule of law.

In another case of Murder of Celina Nebanda a former member of parliament from the opposition side, it had been alleged that Nebanda had died of poisoning orchestrated by the ruling party. The police avoided and delaying in submitting the postmortem report; to show the cause of death of the deceased. For this reason, a private medical pathologist was involved investigating samples that were taken from Nebanda's corpse. The president was quoted saying that: 'This pathologist was arrested because he was not authorized by the Government to test any samples from her body. The police have to minimize the impact of public mistrust in the in their institution and their actions. We don't kill opposition members who have no gun...' Also Dr. Chris Baryomunsi was among those who took part in carrying out the post mortem at Mulago Hospital when Nebanda passed away. 'Baryomunsi who was called in to help the hospital and Police pathologists decided to steal samples together with his colleagues, the President accused kinkizi East Member of Parliament Dr. Chris Baryomunsi of 'stealing the Late Cerinah Nebanda's body samples from Mulago Hospital' the President said.The President also faulted Members of Parliament for going to the mortuary saying it is unheard of for lawmakers to go to the mortuary. The death of the former vocal MP has since been shrouded in mystery with many disputing the government explanation about her demise. Dr.Sylvestre Onzivua was arrested at Entebbe International Airport on his way to South Africa, however the President said the Doctor was not acting within the law and that is why he was apprehended. President Museveni has warned that Government will not tolerate MPs interfering with Police work. ${ }^{46}$ At the end of the day, the police came up with a fabricated postmortem report which indicated high cocaine levels in the body of the deceased. This marked the absurd end of this case. All this serves to confirm how conflicting interest can defeat collaborative investigation.

\section{Novelty and Complexity of Cases}

Due to institutional changes and technological innovations, crimes have taken a different forms apart from the well-known and familiar offence. The current complex, novel and diverse types of offences require new investigative techniques which most of the investiga-

constitutionality of the criminal proceedings brought by private prosecutors against IGP and his junior officers; saying the said charges arise from acts done in execution of the men's official duties.

46 MP Baryomunsi Stole Nebanda's Samples; http://www.redpepper.co.ug/mp-baryomunsi-stole-neb andas-samples-President; An autopsy report released on Saturday evening by Ministry of Health Officials revealed that chemicals such as cocaine, heroin and alcohol were found in the blood samples of the deceased, a report that has since been dismissed by her colleagues and family members. President Museveni defended Police's action of arresting the Doctor hired by the family of the deceased to take body samples to South Africa for further examination. 
tive institutions are not familiar with. Such cases require specialized knowledge for scientific analysis of information, data processing, and sometimes international cooperation and so forth. The police are also expected to react flexibly and expeditiously to the modern forms of crime, if this is not done, this would defeat the purpose of collaborative investigation.

A case in point is one where the recently established Financial Intelligence Authority (FIA) is investigating its very first case where it was revealed that fifty-seven people with links in Uganda are among 100,000 clients of a giant Swiss bank. Out of the 57 HSBC clients associated with Uganda, seven have a Ugandan passport or nationality. These 57 clients held a total of $\$ 89.3 \mathrm{~m}$ with clients associated with Uganda who held the highest amount standing at $\$ 8.8 \mathrm{~m}$. As such, Uganda was also ranked third in East African Community and $105^{\text {th }}$ in the world among the countries with the largest dollar amounts in the leaked Swiss files followed by Kenya and Tanzania. ${ }^{47}$ Yet the FIA does not have the capacity to investigate all these allegations.

Part V of the Act ${ }^{48}$ provides an elaborate procedure that can be used to identify and confiscate proceeds of the crime. ${ }^{49}$ This Part of the Act requires a court order for seizure, freezing and forfeiture of assets. In other Acts such as the Evidence (Book Bankers) Act, financial information cannot be obtained without a court order. An individual or a corporation seeking to commence a private prosecution or investigating internal fraud may require a court order. The Act also covers various forms of electronic transfer of funds through banks, financial institutions and other channels used by natural and legal persons to carry out such transfers. Whereas FIA is the entity in charge of investigations, yet it lacks all the requisite knowhow to investigate this case; hence, there is need for collaboration with the relevant department to obtain sufficient evidence.

Similarly, in Uganda v. Ssekabira \&10 Others ${ }^{50}$ in this case, of the original 24 persons charged with the offence of terrorism, contrary to section 7(1) (b) and 7(2) (c) of the AntiTerrorism Act, 2002, the state withdrew the charge against one Paul Luzikala and a one Joseph Katamba was dropped at the commitment stage. Later on, the case was discontinued against eleven accused persons. Justice Ralph Ochan, held that: "The third schedule to the Anti-terrorism Act has the effect of conferring powers to obtain information for purposes of terrorist investigations, namely, investigations into the commission, preparations or instigation of:

1. Acts of terrorism

2. Any other act which constitutes an offence under this Act.

It is the carrying out above acts which constitutes investigation and this is the preserve of the Investigation Officer as defined the Third Schedule. It is on Court record and in the po-

47 Seven Ugandans Hiding Billions in Swiss Bank, Daily Monitor, Tuesday, February, 10, 2015, p.4.

48 Anti-Money Laundering Act, 2013.

49 This is in tandem with Articles 15-22 of UNCAC.

50 UHC.Cr.Case No.85 of 2010. 
lice statement that Detective Constable Okello John Stephen was the "Investigation Officer" in this case. He does not qualify under the law to undertake terrorism investigation. And by the way an investigation officer does not have to do everything in the process of investigation by himself. He is in charge of the investigation which enables him supervise and oversee the details of the process such as recording of statements, drawing sketch plan, site visits by Scene of Crime Officer (SOCO) among others. I find that in this case there was a violation of S 17 (1) and the Third Schedule of the ATA, 2002 in that the designated Investigation Officer was below the rank of Superintendent of Police. The entire investigation is incurably tainted, rendering the prosecution a nullity. This case failed because both the Police and the prosecution, in their desire ignored the basic and elementary requirements. This investigation should have been carried out by the requisite entity as provided in the law.

\section{Masterminded and Fabricated Cases}

Masterminded and fabricated cases against the opposition are very common in Uganda. Given the nature of these cases, there is no room for investigative collaboration. A case in point is that of Dr. Kizza Besigye the leader of the Forum for Democratic Change (FDC), the opposition political party with the largest number of parliamentary seats in the country. ${ }^{51}$ In the 2001 Presidential elections, he contested and lost the race to President Yoweri Kaguta Museveni. Besigye contested the results in Uganda's Supreme Court and lost the suit on the grounds that the rigging and other election malpractices did not substantially affect the results. ${ }^{52}$ After losing the presidential election petition, there was considerable anxiety and suspicion not only in Government, but also among the general public as to what the retired colonel's next move would be. ${ }^{53}$ Indeed, Besigye was trailed by military and intelligence personnel wherever he went. As a consequence, he filed a matter with the Uganda Human Rights Commission (UHRC) alleging that his life was in danger because of persons who were trailing him whose intentions were not clear. ${ }^{54}$ Following allegations that he was collaborating with rebel movements operating in western Uganda at the time, Besigye was placed under house arrest.

51 Naluwairo, R., The Trials and Tribulations of Besigye, and 22 Others, A Critical Evaluation of the Role of the General Court Martial in the Administration of Justice in Uganda, (HURIPEC Working Paper No.1.October, 2006,), p. 4. ISBN 9970-511-00-8. During the 2006 Presidential Elections, FDC won $37 \%$ of the total votes against its next rival, the Democratic Party (DP) which garnered $1 \%$. The ruling party, National Resistance Movement Organisation (NRMO) won 59\%.

52 Col (Rtd) Dr. Besigye Kizza v. Museveni Yoweri Kaguta and the Electoral Commission, Supreme Court Presidential Election Petition No. 1, 2001.

53 Ibid.

54 UHRC 177/2001, Rtd. Col. Dr. Kizza Besigye v. Attorney General (Chieftaincy of Military Intelligence). 
Fearing for his life, he fled the country to South Africa where he was exiled until October 2005 when he returned to contest the 2006 presidential elections. Between the year 2003 and the beginning of 2005, a number of alleged rebels including 22 others who were subsequently charged along with Besigye, were caught in various places in the Democratic Republic of Congo (DRC) and Uganda. The Government alleged that they had linkages with the Peoples' Redemption Army (PRA), a rebel movement that had also been associated with Besigye. The 22 were detained in various military establishments around the country and were never charged or tried in any court of law until Besigye's return in late 2005.

Shortly after his return, Besigye was arrested and jointly charged with the 22 others with treason and misprision of treason under the Penal Code Act. ${ }^{55}$ The indictment was read to them at Buganda Road Chief Magistrates' Court. The first accused (Rtd. Col. Dr. Besigye) was separately charged with the offence of rape allegedly committed in 1997.

The High Court acquitted Besigye of the rape charges. In his judgment, while quoting Lord Brougham's speech in support of Queen Caroline, Justice Bosco Katutsi held that 'the evidence before court was inadequate even to prove a debt; impotent to deprive of a civil right; ridiculous for convicting of the pettiest offence; scandalous if brought forward to support a charge of any grave character; and monstrous if to ruin the honour of a man who offered himself as a candidate for the highest office of this country. ${ }^{56}$ All the accused were subsequently committed to the High Court for trial.11 On November 16th, 2005, the accused were taken to the High Court for a bail application before Justice Lugayizi. Fourteen of the accused were granted bail. As the hearing was proceeding, armed security personnel dressed in black raided the court premises, and surrounded the holding cells in which the successful bail applicants were waiting to be released.

As a result of this action, the bail papers could not be processed. The armed personnel (who subsequently came to be dubbed "Black Mambas" by the media) entered into some of the offices and interrupted the court's normal duty of processing bail. The accused were thus returned to prison in order to ensure that they faced new charges that had been brought against them in the GCM. ${ }^{57}$ The attack of the High Court premises by the Black Mambas was widely condemned not only in Uganda but world over. In the words of Justice James Ogoola, the Principal Judge of High Court, he condemned it as a 'naked rape, defilement and desecration of our temple of justice. Not since the abduction of Chief Justice Ben Kiwanuka from the premises of Court during the diabolical days of Idi Amin has the High Court been subjected to such horrendous onslaught as witnessed last Wednesday.' Indeed, the following day on November 17th, 2005, all the accused persons including Besigye were

55 Cap.120 Laws of Uganda, 2000.

56 For details of Justice Bosco Katutsi's judgement, see, Col (Rtd) Dr. Kiiza Besigye v. Uganda, High Court Criminal Session No. 149/2005.

57 G. Sseruyange, Black Mambas intended to re-arrest PRA suspects, The Daily Monitor, Thursday November 17, 2005. 
taken to Makindye and jointly charged in the GCM with the offence of Terrorism, ${ }^{58}$ and in the alternative with being in unlawful possession of firearms. ${ }^{59}$ All the offences arose from the same facts as the treason and misprision of treason charges previously preferred against them in the High Court. ${ }^{60}$

Similarly, following the recent 2016 presidential elections, Besigye faced yet other fresh charges of treason and was remanded. ${ }^{61}$ After his arrest on Wednesday a week when he skirted a 24-hour security surveillance at his Kasangati home and made a surprise appearance in Kampala City, Dr. Besigye was charged with treason at Moroto Chief Magistrates Court on May 13 and remanded to Moroto prison where he spent three days. He was transferred to Luzira prison on Monday after his relatives secured a production warrant. Prosecution alleged that Besigye and others at large between February 20 and May 11, 2016, in diverse places of Uganda formed an intention to compel by force or constrain the government of Uganda as by law established to change its measures or counsels as to the lawfully established methods of acceding to the office of president of the Republic of Uganda as by law prescribed and manifested such intention by overt acts and utterances such as:

1. Between February 20 and May 20,2016 at various places in Wakiso and Kampala District Besigye demanded an independent international audit to be conducted before a new president was sworn in.

2. On April 7, 2016, at Kasangati in Wakiso District, Dr. Besigye uttered words to the effect that he would establish a cabinet for the Republic of Uganda

3. Between February 20 and May 11, 2016 at various places in the districts of Kampala and Wakiso District, Besigye declared himself the winner of presidential elections.

4. Between February 20 and May 11, 2016 at various places in the districts of Kampala and Wakiso District Besigye defied lawful authority and mobilized people to his swearing as president of the republic of Uganda.

5. Dr. Besigye unlawfully took the oath of presidency and undertook to execute the functions of the office of the president of the republic of Uganda.

As event kept unfolding, Besigye was later transferred to Luzira prison and charged in Nakawa Chief Magistrates Court. Before the mentioning of the case could be done, the State ordered court to transfer the trial to Luzira Court which is near Luzira Prison citing public security threats which the court refused to grant. ${ }^{62}$

58 Terrorism is an offence created under the Anti-Terrorism Act. Act No. 14 of 2002.

59 Unlawful possession of fire arms is an offence under the Fire Arms Act Cap 299, Vol. XII, Laws of Uganda, 2000.

60 H. Bogere, Govt Bans Talk On Colonel's Court Case, The Daily Monitor, Thursday November 24, 2005.

61 Wekesa, A., Besigye Charged Afresh with Treason, Further remanded, Daily Monitor, 18/05/2016.

62 Uganda v. Kizza Besigye Kifeefe MOR-CR-AA-016 of 2016 (before His Worship Ereemye Jumire (Chief Magistrate).State orders Nakawa Chief Magistrate Court to Move to Luzira Court and have this case called and mentioned there until when the accused shall be committed for trial to the 
Besigye was later granted bail and he travelled to the UK. ${ }^{63}$ Analysts have stated that this is yet another masterminded case, cooked in the state house to satisfy the selfish motives of the ruling party and suffocate the opposition-an abuse to good government and rule of law. Such concocted cases remain a big challenge for the collaboration of the investigative agencies in Uganda. It can be seen that the government sets up non-existent evidence to protect her political havens which undermines gives no room for collaborative investigation.

\section{Violation of Human Rights by Investigative Agencies.}

As investigative agencies carry out their duties, it may be necessary to curtail some of the freedoms of an individual. For instance, after arrest, the suspect is deprive of freedom of movement, association among others. It should however be noted that: The fundamental rights and freedoms of the suspect must at all times be protected. In case of violation, it should be noted that no matter how sufficient the evidence obtained during investigation may be, court cannot convict the offenders on the basis of such tainted evidence. In Dr. Kiiza Besigye v. $\mathrm{AG}^{64}$ the petitioner, Besigye applied to the constitutional court following the violation of his fundamental rights namely; right to a fair trial, right to bail and freedom from double jeopardy. The Constitutional Court stated that:

"This Court cannot sanction any continued prosecution of the petitioners where $d u$ ring the proceedings the human rights of the petitioners have been violated to the extent described above. No matter how strong the evidence against them may be, no

High Court or the decisions of the DPP. The prosecution cited security threats as the reason behind the transfer. Further, the prosecution cited that Luzira Court is near Luzira prisons where the respondent had been detained. His Worship Ereemye stated that the submissions of the prosecution were not supported by any evidence that this court would premise its findings to move the mentioning of this case to another place under section 7 of the Magistrates Court Act, Cap.16. whose purpose was to enhance the ends of justice where accessibility to the court house is in issue for the transaction of legal business. And if security was the concern, no guarantees were told to the court. All this was mere heresay, and the prosecution ought to have known that for the court to allow such an application, they should have furnished evidence of such threats. The application was disallowed. Cap 16, Laws of Uganda, 2000 edition. Section 7 thereof states that: 7 'Place of sitting. (1) A magistrate's court-(a) may be held at any place within the local limits of its jurisdiction; or (b)if it appears to the Chief justice that the interest of justice so require, may be held, with the written authorization of the Chief Justice, at a place outside the local limits of its jurisdiction designated in the authorization, and shall be held in such a building as the Chief Justice may, from time to time assign as a court house.(2) Notwithstanding subsection (1), if a magistrate's court sits in any building or place within the local limits of its jurisdiction for the transaction of legal business, the proceedings shall be as valid in every respect as if they had been held in a court house assigned for that purpose.'.

63 Dr. Kizza Besigye v. Uganda Criminal Application No.83 of 2016.

64 Constitutional Petition No. 7 of 2007. 
fair trial can be achieved and subsequent trial would be a waste of time and an abuse of court process".

Similarly, in Ug v. Kalawudio Wamala ${ }^{65}$ at the High Court at Masaka, the accused Kalawudio Wamala was taken into Police custody on $13^{\text {th }}$ September 1994, long after 48 hours since his arrest. Egonda Ntende J, had this to say.

"The Constitution has set a new threshold for all organs and agencies of government and persons, including men and women serving in those organs and agencies. It positively commands all agencies and organs of government to respect uphold and promote the fundamental rights and freedoms set forth in the Constitution. This imports, in my view that each officer is beholden, in carrying on his duties, to respect, or uphold and promote those rights and freedoms. Where an officer of an organ or agency of government fails to respect or uphold or promote the rights and freedoms set forth in Bill of rights (chapter 4) such officer and consequently the organ or openly he/she belongs to is in breach of Article 20(2) of Constitution..."

In collaborative investigation, there is a high likelihood that one or more of the investigative institutions violates the suspect's right and no matter the quality of the evidence obtained against the suspect, courts cannot use it to secure a conviction hence defeating the ends of justice.

\section{Psychological Traits of the Police and Prosecutors}

After undergoing lengthy, laborious and complicated investigation process, police investigators generally tend to develop a feeling of exclusiveness, and feel that the entire investigation domain is their responsibility. As a result any sort of advice and instruction from outside is taken as interference and unnecessary. Resistance is shown if they are told to bring more substantial evidence, or amend or improve the evidence collected. Police officers and organizations tend to take their entire work and especially the case handling as a professional and skilled job. Though they work and do the investigation within their own legal, and procedural codes, their practical and operational framework makes them believe that they have their own chain of command system which works as efficiently as prosecutorial agencies and which they believe, can provide them guidance and instructions. ${ }^{66}$

\section{Learning to Collaborate}

According to Anne Puonti, the learning challenge in the collaborative investigation of crimes is manifold. It is easy for individuals to effectively work together across organizational boundaries. The object of the work and the motive of the activity cannot be taken for granted they are not necessarily shared. Each participant in an investigation process has a 
specific, partial point of view. The participant institution have different tasks, goals, working procedures and organizational cultures ${ }^{67}$. Learning to collaborate does not automatically take place in the investigation process because disturbances, deficient communication, ruptures and mundane innovations as signals of underlying developmental tensions. Thus possibilities in a collaborative investigation process call for qualitatively new ways of interaction, new tools and instruments of investigation.

\section{Information Sharing}

This, again, raises the question of transfer: how to share knowledge and practices better across organizations? The sequential crime-investigation model is based mainly upon information exchange rather than on shared knowledge creation. The distinction between information and knowledge is not well articulated in the investigation practice. The exchange of information from one person to another or across organizations is not sufficient for advanced collaboration, which implies constructing the object together. Collaboration calls for shared creation of knowledge in the heterogeneous investigation groups. ${ }^{68}$ The divergent perspectives and knowledge resources are an opportunity for the creation of something more than any single participant could invent alone. The myth of the investigator solving crimes with intuitive methods alone is outdated. However, the challenge of collective knowledge creation seems to be large: members of hierarchical organizations based on rigidly defined top-down relationships should share their information and knowledge that have been carefully kept inside the organizations for a long time. Moreover, when the collaborative investigation is successful, it results in increasing amounts of information in the form of documents and knowledgeable personnel. ${ }^{69}$

\section{Conflicting Views over Case Disposition}

The police feel frustrated when the prosecutors' case-disposition conflicts with the expectations of the police. It is totally disappointing for investigators if an arrested suspect is set free by prosecutors on the ground that the prerequisites have not been fulfilled for keeping the suspect in custody, or where investigatory activity despite the great deal of time and effort involved leads to the termination of the proceedings. It was pointed out that in such cases prosecutors also feel stress, which may lead to negative influence on the working relation between the police and prosecutors. ${ }^{70}$

67 Anne Puonti, "Learning To Work Together: Collaboration between Authorities in Economic-Crime Investigation", University of Helsinki Faculty of Behavioural Sciences Center for Activity Theory and Developmental Work Research, (Vantaa Finland, 2004), p.11.

68 Ibid.

69 Supra.

70 Supra. 


\section{Lack of Shared/Common Goals among Investigative Institutions}

There is lack of confluence in the aims and objectives of the investigative agencies in Uganda. The lack of sharing common goals with other investigative institutions makes it impossible to motivate investigative institutions to produce quality files. In order to make such a relationship more effective, both sides should make efforts to understand and respect each other's responsibility investigation. ${ }^{71}$

\section{H. CONCLUSION}

In final analysis collaborative investigation is the way to go for Uganda. As such, Uganda should fully embrace this notion in her investigation processes. In light of the above discussion, expertise presupposes interaction between the subjects and their activity systems, and learning experiences that emerge in this interaction. The investigative collaboration will not be easy given the fact that the many challenges and mutual suspicion may hamper it. All in all, this may call for rethinking of institution investigative organizational relationships. Instead of seeing the investigation process as a series of successive phases with responsible actors from various authorities, the investigation process may be viewed as a fluid entity comprised of input from various authorities working an object which has been explained and is at least partly shared between the participants to combat crime. This largely requires calls for a discussion of the values and objectives across the relevant institutions.

\section{RECOMMENDATIONS}

In light of the above discussion and conclusion, with a view of ensuring and enhancing collaboration between investigative institutions in Uganda, the study makes the following recommendations:

1. There is need for investigative institutions to acquire new knowledge on the basis of the information and mutual interaction. This implies learning; the participants have to learn to collaborate.

2 Sharing Common Values; effective criminal investigation management requires concerted action of all relevant authorities in the government, which have the same ultimate goal of realization of the rule of law. Those authorities should share substantial common values which are supported by strong political will.

3 More Communication; the key to the good working relation among investigative institutions is the promotion of mutual understanding through informal institution-institution contact.

71 Interview with AIP Mugume Charles, Central Police Station Kampala, 17/08/2016. 
4 Regular Meetings and Seminars; regular meetings at least once a month or quarterly would be beneficial as this would lead to coordinated and simplified investigations.

5 Investigative institutions must take heed to established procedures in execution of their duties.

\section{BIBLIOGRAPHY}

Constitution of Republic of Uganda, 1995 (as amended)

\section{List of Statutes}

Criminal Procedure Code Act, Cap.116, Laws of Uganda, 2000.

Penal Code Act Cap.120, Laws of Uganda, 2000.

Anti-Corruption Act 6, of 2009.

Inspectorate of Government Act, 2002.

Anti-Money Laundering Act, 2013.

\section{Textbooks}

Anne Puonti, Learning To Work Together: Collaboration between Authorities in Economic-

Crime Investigation, University of Helsinki Faculty of Behavioural Sciences Center for Activity Theory and Developmental Work Research, (National Bureau of Investigation, Vantaa Finland, 2004.), pp.9, 11, 35. ISBN 952-10-1702-3.

Bayley, D., Police for the Future, (Oxford, 1994.)

Bowling, B. and Foster, J., Policing and the Police, In M. Maguire, R. Morgan and R: Reiner (Eds), the Oxford Handbook of Criminology Oxford, (Oxford University Press.2002.) ISBN: 9780199590278.

Bryan, A., Garner, (editor), Black's Law Dictionary, West Publishing Co., (8 ${ }^{\text {th }}$ Edition, 1990.), p.844. ISBN 90-6544-631-1.

Eck, J. E., Rethinking Detective Management: Why Investigative Reforms Are Seldom Permanent or Effective, In D. J. Kenney and R. P. Mc Namara (editions) Police and Policing, Contemporary Issues, (Westport: Praeger, 1999.) ISBN-13:9780275954987, Price \$94.25.

Naluwairo, R., The Trials and Tribulations of Besigye, and 22 Others, A Critical Evaluation of the Role of the General Court Martial in the Administration of Justice in Uganda, (HURIPEC Working Paper No.1.October, 2006,) p. 4. ISBN 9970-511-00-8.

Skolnick, J. and Bayley, D., The New Blue Line. Police Innovation in Six American Cities,(New York: The Free Press, 1086, 1986.)

Uganda Judicial Commission of Inquiry: Report of the Judicial Commission of Inquiry into Corruption in the Uganda Police Force, Main Report, 10 (1999-2000). 